\title{
Model of Ulayat Land Registration in Pakraman Village in Bali
}

\author{
I Made Suwitra ${ }^{1}$, I Nyoman Sujana ${ }^{2}$, I Nyoman Alit Puspadma ${ }^{3}$, I Ketut Kasta Arya Wijaya ${ }^{4}$, \\ Ni Putu Sawitri Nandari ${ }^{5}$ \\ madesuwitra@yahoo.co.id ${ }^{1}$, manjana@indo.net.id ${ }^{2}$, alit_notarisbadung@yahoo.com³ \\ kastaaryawijaya@gmail.com ${ }^{4}$, sawitrinandari@gmail.com ${ }^{5}$ \\ Warmadewa University Denpasar-Bali, Indonesia ${ }^{1234}$ \\ Universitas Pendidikan Nasional, Denpasar-Bali, Indonesia ${ }^{5}$
}

\begin{abstract}
This study aims to find a registration model for the ulayat land of Pakraman (customary) Village in Bali after the issuence of Decree of the Minister of Agrarian and Spatial Planning/Head of the National Land Agency No. 276 / KEP-19.2 / X / 2017. From the results of previous research, a portion of ulayat land in each Pakraman village in Bali has been registered under state law to be individual land. The research method used is in the form of normative legal research with a legal, analytical and case approach through analyzing relevant laws and regulations and documents. Its findings are ulayat land which is controlled jointly by family groups or individually registered and issued certificates of ownership in the name of Pakraman Village. This registration model is presumed to have the implication of shifting the existence of ulayat land towards communal land, the shifting of tenure rights that is public as well as private to the right of communal ownership which has private dimension, and the appaer of the dominance of ownership rights over communal land by Pakraman Village.
\end{abstract}

Keywords: Pakraman village, land registration, free hold title, ulayat land, communal land.

\section{Introduction}

Bali as one of customary law alliance called the Adat Village or Pakraman Village in the Regional Regulation of Bali Province No. 3/2001 jo 3/2003 [1] holds a variety of mysteries, especially regarding iulayat land. In the dissertation research I Made Suwitra, it was found that a portion of ulayat land in the majority of Pakraman villages had been converted into full individual land which was registered through conversion according to state law. [2] the individualization of the ulayat land of Pakraman Village occurred because there was no comprehensive understanding of the implications of registration under the state law. The people of Pakraman Village consider that the registration of ulayat land is intended to strengthen the control of ulayat land which is subject to customary law. However, due to the registration of communal land, which ensured the subject of ownership actually led to the transfer of ownership according to religious communal customary law towards ownership according to the secular individual state law. [2] The legal assurance that this state law wants 
to realize in fact causes conflict in almost all districts in Bali against the claim of ownership of ex-communal land.

The purpose of this study is to analyze and compare some of the idea of the educators and sociologists to find harmonization of concepts towards the registration model of ulayat land in Pakraman Village in Bali after the enactment of the Minister of Agrarian and Spatial Planning / Head of the National Land Agency No. 276 / KEP-19.2 / X / 2017 (Kepmen ATR / Ka.BPN 276/2027) concerning the Appointment of Pakraman Village in Bali Province as the Subject of Communal Rights to Land [3], hence the mandate of assurance and legal protection by state law can coexist with customary law, especially regarding the existence of ulayat land in Pakraman Village. In addition, with the existence of a target-oriented Complete Systematic Land Registration (PTSL) program as an indicator of success, it does not make the customary land area as a second "victim" when the land registration policy is issued through the National Agrarian Operations Project (PRONA). in the Decree of the Minister of Home Affairs (Kepmendagri) No. 189 of 1981 whose main purpose is to process mass land ownership as an embodiment of the Four Orderly Program in Land which is carried out in an integrated manner, especially for the people of the weak economic group, as well as complete resolution of strategic land disputes.

Conflicts over customary land claims after registration according to state law either through conversion or through PRONA program have occurred in various districts in Bali, such as in Pakraman Village of Panji, Lemukih Village, Kubutambahan Village, Kemenuh Village, Bunutin Village, Culik Village, Ngis Village, Tusan Village, Kusumasari, Tegal Gundul Village, Yang Api Village.[4] Claims made by Pakraman Village were resolved through litigation or mediation, even Coercion. There is a time when the status of the mastering or ownership of the Village can be restored, like in the Culik Village of Karangasem, Kubutambahan Village of Buleleng. Customary lands which have become ownership rights both individually and communally then after being re-used as the land of the Desa Temple. After the issuance of Decree of Minister of Agrarian and Spatial Planning / Head of the National Land Agency No. 276/2017 which appointed Pakraman Village in Bali as the subject of communal ownership of land, in one hand it became a matter of pride in the legal structures in Bali such as the Majelis Utama (Main Assembly) of the Village of Pakraman village, customary expert, Senator, Bendesa Adat (the head of customary village) because he felt he had succeeded in fighting for Pakraman Village as a "Legal Subject" who could have the right to "customary land". But on the other hand another implication needs to be taken into account, namely the domination of customary land conversion into communal land. In addition, the dominance of Pakraman Village is also dominated by communal land which has been controlled individually, which is combined with hereditary rights such as Land of Pekarangan desa (village yard) (PKD) or Ayahan Desa (AYDS).

In the research of Anak Agung Ayu Intan Puspadewi et al., It was stated, (1) the meaning of communal concepts on land used in Decree of Minister of Agrarian and Spatial Planning/Head of the National Land Agency No. 276/2017 emphasizes that communal rights in question constitute joint ownership rights of indigenous peoples in Bali Province and are on land that can be registered according to the recognition of the government and the local community, (2) the juridical consequences of Decreee of Minister of Agrarian and Spatial Planning/Head of the National Land Agency No. 276/2017 towards Pakraman Village as the subject of communal ownership rights over land, that Pakraman Village is explicitly acknowledged as the subject of communal ownership rights over land, Pakraman Village has the obligation to register land to the land office then a land title certificate is awarded through the process and procedures specified in the Governemnt regulation on Land Registration and 
Minister of of Agrarian and Spatial Planning/Head of the National Land Agency Regulation No.10 of 2016. Pakraman village is the subject of communal ownership of land after carrying out the land registration of Pakraman Village has the right to make agreements with third parties according to the agreement. [5]

I Ketut Sudantra in his paper entitled "certification of customary land in Bali", diagnosing the implications of the appointment of Pakraman Village as the subject of communal rights to land "said that the appointment of Pakraman Village as the subject of joint ownership rights (communal rights) on land resulted in juridical, sociological and philosophical. [5]The juridical implications of the appointment involve certainty of the status of rights from village land. Based on Ministerial Decree of grarioan nd Spatial planning/The Head nationalland Agency No 276, the rights status of village land is communal rights as conceptualized by the Minister of Agrarian and Spatial Planning / Head of the National Land Agency of the Republic of Indonesia No.10 of 2016 (Minister Decree of ATR 10/2016). [6] Then according to the second dictum of the Decree of the ATR 276/2017, the rights of village land can be registered based on the recognition of the Government and the local community in accordance with applicable regulations. The procedure for recognizing and establishing these rights is determined in detail in the 2017 Communal Rights Ministerial Regulation. The registration of communal rights from village land - which leads to the issuance of land title certificates - may not cause significant problems for the community if the registration concerns the druwe desa land (village owned land), namely village lands that is directly controlled by the village, both used for religious, socio-cultural and economic functions. In fact, the registration of druwe desa land is very good for guaranteeing legal assurance and certainty of the land rights. However, for village lands that have been controlled by individual village officials, both in the form of pekarangan desa land and Ayahan desa land, whether the character of the customary land are still strong, weakened or may have fled, the registration may face its own problems in its implementation in the community. It is important to ascertain the certificate model that is the output of the registration process, for example concerning as the subject of the rights stated in the certificate, whether in the name of the village or in the name of individual village officials. If in the name of the village, there is the possibility of resistance from the villagers who controls the land, especially the lands of pekarangan desa or ayahan desa land, whose character of individual rights has been so strong. Conversely, if the subject of the rights stated in the certificate is individual village officials, besides being able to obscure - even eliminate altogether - the character of the customary land from the land rights, it will also be a separate problem if there are more village families who control the village land. from an heir. Which heirs are listed as subjects of rights in the certificate? These sociological problems are important to understand and discuss so that the best models can be found in registering village land, especially those that have been controlled by individuals. Ideally, all village lands - both those that are controlled and used directly by the village as well as those that have been submitted to individual village officials - are registered by listing Pakraman village as the subject of their rights. On the land of communal rights Pakraman village can then be placed the rights of village manners on the land, which is regulated internally and autonomously by the Pakaraman village through customary regulations (awig-awig) or decisions of the Pakraman village (pararem). With this type of registration, the relations of Pakraman village with land can still be maintained, where the village can still interfere with the land. If the registration (certification) of individually controlled village land is carried out by listing the subject matter of rights in accordance with the subject in control at the time of registration, it is feared that it will cause separate problems in the future. Moreover, the registration will weaken the character of customary land and 
strengthen the character of individual rights from the land. If such conditions occur, instead of wanting to strengthen the existence of Pakraman Village, on the contrary the registration will weaken the existence of Pakraman Village itself.

I Made Suwitra, I Nyoman Alit Puspadma in his paper entitled: "The Legal certainty Perspective on Ulayat Land Ownership in Bali" published by Atlantis Press, states: The issuance of ATR 10/2016 jo Minister Decree ATR 276/2017 is also intended to protect the existence of the Ulayat Land of Pakraman Village, the status of the Communal Land. The status into a Communal Land, even with PTSL as Ulayat land which is individually will be converted into individual property rights according to the law which results in the extinction of Ulayat land intended. [7]

In a paper entitled: "Registration of Right to Customary Land in Bali in the National Agrarian Law Perspective", it was concluded that for communal-controlled customary land there was registered evidence of Property Rights (SHM) in the name of temple since 1986, but still exists some have not been registered as setra (cemetary) land, market land, field land. Therefore for this customary land by following the norms in Article 2 Section (4) of Act No. 5 of 1960 concerning the Basic Agrarian Law (BAL) [8] can be given a Management Rights Certificate (HPL) as well as private land assets, such as Provincial, Regency or City Governments that reflect communal religious concepts that are the main ingredients for the establishment of the BAL. While for customary lands which are controlled individually, such as PKD and AYDS land, most of them have been converted into full individual land rights (SHM). The enactment of the Decree of the ATR 276/2017 can be used as an opportunity for Pakraman Village to certify its customary lands which are controlled communally or individually that have not been registered in the name of Pakraman Village. can have Communal Ownership rights. However, in terms of law hierarchy, it does not fulfill legal certainty because it is contradictory or duplicates with the intention of the provisions of Article 2 Section (4) of the BAL. Therefore the Agrarian Ministerial Decree No.276 of 2017 does not have the power toforce. [9]

From some of the results of the insights that have been conveyed, the important legal issue in this paper is determining the registration model of ulayat land in Pakraman Village in Bali. This condition is considered urgent by remembering past experiences that show the emergence of various conflicts as a result of registering ulayat land or customary land both as Pura druwe land 9Lnd owned by the tempe) or Desa druwe land (land owned by the village).

\section{Methodology}

The type of research used in constructing of this paper is normative legal research considering the duplication of norms between Decree ATR 276/2017, Minister of Agrarian and Spatial planning Decree/The head national land Agency No 10/2016 with BAL and Governemnt Regulation 24/1997 concerning the concept of Ulayat Rights and Communal Rights, appointment of legal subjects only private dimensions, and land registration objects. The problem approach is to use the statutory approach, concepts, analytics, and cases. The source of legal material is in the form of primary legal materials and secondary legal materials which are then analyzed by hermenetic techniques. 


\section{Result and Discussion}

\subsection{Land Registation System}

Article 19 of the BAL mandates the registration of land throughout Indonesia to ensure legal certainty. The intended registration includes:

a. ground measurement and bookkeeping;

b. registration of land rights and the transfer of these rights;

c. the granting of proof of rights documents, which applies as a strong evidence tool.

Registration object according to Article 9 Section (1) Government Regulation No. 24 of 1997 concerning Land Registration (PP 24/1997) includes: (1) The object of land registration includes: (a) Plots of land owned by ownership rights, business use rights, building use rights, and usufructuary rights; (b) land management rights; (c) waqf land; (d) ownership rights of apartment units; (e). mortgage right; (f). State land [10]. In addition, there are two kinds of land registration activities, namely: first, land registration activities for the first time, and second, activities for maintaining land registration data. The registration activity for the first time is land registration activities carried out on objects of land registration that have not been registered under Government Regulation No. 10 of 1961 which was later replaced with Government Regulation 24/1997. Land registration for the first time is done through systematic registration of land or sporadically.

Regarding to the provisions of Article 19 Section (2)c of the BAL stating that: Provision of proof of rights documents, which applies as a strong evidentiary tool, Boedi Harsono interprets that the BAL adheres to a "negative which contains positive element" publication system, because will produce proof of valid rights as a strong evidentiary instrument. [11] So the proof of the right is valid as evidence, meaning that the statements contained therein have legal force and must be accepted (by the judge) as true information, for as long as there is no other proof of evidence that proves otherwise. In this condition, the court will decide which verification tool is correct, then changes and corrections will be held as needed.

\subsection{The Model of Ulayat Land Registration}

\subsubsection{The Model of Free Hold Title}

The Governor of Bali in 1986, dated April 17, 1986 No. 593.2116017 / B.B.Pem and date of June 10, 1986 No.593.211 / 13568 / B.B Pem. Propose to the Minister of Home Affairs that "Customary Villages and Temples can be established as legal entities entitled to own land". Through the Decree of the Minister of Home Affairs No: SK.556 / DJA / 1986 (Kepmendagri 556/1986) stipulated: First, Appoint Temple as a religious legal entity that can have Ownership Rights on Land. Secondly, Palemahan lands which are functional units with Temple already owned at the time of stipulation of this decree, converted into ownership rights.[12]

The issuance of Deree of Minister of Home Affairs (Kepmendagri) 556/1986 implies that the registration of communal land is utilized and used as Laba pura (Temple Land) through conversion on behalf of temple. However, it is registered only on communal land with status as Pura profit in the form of rice fields and/or moor only, while for palemahan, which is a function unit with Pura, it has not yet been registered. This is where the weirdness is. So, all types of Laba pura (Temple Land) can be deposited in the name of Temple, such as Banjar 
Temple, Dadia or Paibon temple which belong to a particular clan group called communal land, Kahyangan Tiga or Kahyangan Jagat Temple.

Considering this condition can be interpreted, that the ulayat land of Pakraman Village in Bali which was used as the object of land registration was limited to the land of Laba Pura, while other types of communal land such as Market land, Cemetary land, Tanah Pekarangan desa (PKD), Ayahan Desa land (AYDS) cannot be certified in the name of the Village. The strengthening of the existence of Ulayat lands can be done through registration in the Basic Map of Land Registration by putting a cartographic sign as mandated in Article 5 Section (1) Regulation of the Minister of Agrarian Affairs / Head of the National Land Agency Number 5 of 1999 (Permenag / Ka. BPN 5/1999). [13] For further implementation, it is mandated to be regulated by Regional Regulation (Perda). Until now, the Regional Government, both provincial and district/city, had never existed. The implication of customary land other than practical laba pura (temple land) has not been stated in the basic land registration map.

Issuance of Minister Decree of Agrarian and Spatial Planning / Head of National Land Agency No. 9 of 2015 (Permen ATR / Ka.BPN 9/2015) concerning Procedures for Determining Communal Rights to Land of Customary Law Communities and Communities in Specific Areas intended to strengthen the rights of indigenous peoples (MHA) called Communal Rights, where These Communal Rights have different characteristics from Customary Rights. This regulation was later revoked by Agrarian Regulation No. 10 of 2016 concerning Procedures for Determining Communal Rights on Land of Customary Law Communities and Communities in Certain Areas [14]

These ulayat rights have both public and private dimensions. The public dimension appears within the authority of the MHA to regulate (1) land/territory as its living space related to its utilization including its maintenance; (2) legal relationship between MHA and its land; and (3) legal actions related to the land of MHA. The private dimension of customary rights appears in the manifestation of communal rights as common property. Ulayat rights are not land rights as intended in Article 4 in conjunction with Article 16 of the BAL. On the contrary, the $\mathrm{HK}$ on the land is defined as land rights (Article 1 point 10 of the Minister decree). The consequence of categorizing Communal Rights as Land Rights, can be disserted (Article 13 section 3 of the Minister Regulation). Conversely, because customary rights are not land rights, the existence of customary rights is stated in the basic map of land registration and recorded in the land register. There is no certificate issued on communal land. With the revocation of Permenag / Ka.BPN No. 5/1999, the customary land registration model is no longer clear. [15] It is relevant to the statement of the Indigenous Peoples Alliance of the Archipelago (AMAN), that the Ministry of Agrarian and Spatial Planning is considered to have ignored the reality of land tenure in the community, namely by applying the ATR 9/2015 Permen, which has simplified the concept of Ulayat rights into Communal Rights. [16]

Issuance of Decree of the Minister of Agrarioan nd Spatial Panning/ Had of national land Agency No. 276/2017 which appoints Pakraman Village in the Province of Bali as the Subject of Communal Over Land Rights, which stipulates that the rights of communal ownership of the Pakraman Village that are used for the customary needs of the Pakraman Village can be registered based on Government recognition and local community according to applicable regulations. The question is whether the Ulayat Rights of Pakraman Village are equated with Communal Rights? Or will customary land rights be converted into communal rights to land? Changes in all this certainly have their own implications, especially regarding the existence of customary rights over land that is both public and private. Minister Decree of ATR / Ka.BPN 
No. 276/2017 this is more appropriately utilized for registering Communal Rights land, such as the Pauman land in Karangasem Regency. [17]

Some types of communal land called village land or customary land in Bali, such as Pura Profit, Banjar Upright Land, PKD Land, AYDS Land, for the most part have been registered through conversion to obtain ownership rights both as communal property rights and full individual property rights. Then later it caused conflict. While some areas of ulayat land have not yet been certified, such as Setra land, market land, field land, PKD land, AYDS land, customary forest.

In the framework of registering all land parcels in the Republic of Indonesia as mandated by Article 19 of the BAL, the Government launched an acceleration program for Land Registration through Complete Systematic Land Registration (PTSL) until 2025. Therefore, the President issued Instruction Number: 2 of 2018 concerning Acceleration Complete Systematic Land Registration in the Entire Republic of Indonesia. For the implementation of the intended activities, it is instructed to the Minister of Agrarian Affairs and the ATR / Head of the National Land Agency to the Regents / Mayors.

Each Regency/City through its Head of Land Office makes a decision about the Determination of the Location of Acceleration of the Implementation of Complete Systematic Land Registration which is set out in detail through tabulation with details in each village in their respective sub-districts. As the Decree of the Head of the Tabanan Regency Land Office Number: 69 / KEP.51.02,000 / V / 2018 concerning the Second Amendment to the Determination of the Location of the Acceleration of the Implementation of Complete Systematic Land Registration. [18] thus in the PTSL implementation it is necessary to determine the location of the village / location that is adjusted to the availability of available funds and those that are valid in accordance with the laws and regulations. The number of villages identified in the PTSL activities, namely the establishment of villages that were originally 48 villages into 64 villages with a physical target of 67,000 Free Hold Title in 2018. Customary land which is certified as PKD or AYDS land with the Free Hold Title Model in the name of Pakraman Village

\subsubsection{The Model of Land Registration Basic Map}

In Minister of Agrarian and Spatial Planning/The Head of National Land Agency Regulation No 5/1999 concerning Guidelines for Resolving Customary Rights Issues of Customary Law Communities, a customary land registration model is stated in the basic map of land registration by affixing a cartographic sign, and if possible, delineating its boundaries and recording it in the land register. With the revocation of Minister of Agrarian and Spatial Planning/The Head of National Land Agency Regulation No 5/1999, then by Minister of Agrarian and Spatial Planning/The Head of National Land Agency Regulation No No. 10/2016 this ulayat land was deflected into communal land which was subsequently registered for Free Hold Tittle to be issued in the name of Pakraman Village following Minister of Agrarian and Spatial Planning /The Head of National Land Agency Decree No. 276 / 2017 jo the Instruction of the President of the Republic of Indonesia Number: 2 of 2018. With the design stipulated by the Head of the National Land Agency Office, communal lands which have been individually controlled for generations are then registered through the Complete Systematic registration method called PTSL by including the Pakraman Village as the owner. So there has been a shift in the model, namely Pakraman Village as the subject of communal ownership of PKD land and at the same time establishing Customary Rights as the object of registration. It is very different from the provisions of Article 9 Section (1) of Government 
Regulation No. 24/1997 which does not make communal land an object of land registration. This condition is clearly contrary to the concepts and theories of Gustav Radbruch's legal certainty, that is certainty because of law, and certainty in law or self. [19]

Realizing that the Minister of Agrarian and Spatial Planning/The Head of National Land Agency Regulation No. 5/1999 would be revoked, the DPD RI (region representative Council) through the Law Drafting Committee (PPUU) of the DPD RI then drafted the Draft Bill on the initiative about the Customary Law Bill on Customary Law Society. The material in this bill wants to affirm the model of the preservation and protection of communal land of the Customary Law Community (CLC) through the form of "confirmation". The objectives of the Rights arrangement are:

a. recognizes, respects the right of CLC over Ulayat Rights (UR)

b. realizing legal certainty on Ulayat Rights of CLC

c. Protect rights and strengthen access to CLC over UR

The inauguration of the existence of customary law community customary rights is determined by regional regulations or regional head regulations (Article 7 paragraph 1 of the bill). To the existence of Ulayat Rights of Customary Law Community (CLC) which contains public and private elements is stated in the basic map of land registration by affixing a cartographic sign that describes its boundaries and records it in the land register (Article 7 paragraph 2 of the Draft Bill). As for the existence of customary rights, customary law communities that contain private elements are registered according to the laws and regulations (Article 7 Section 3).

This bill also provides a way for CLC to work on their customary land according to state law, so that on the one hand the existence of customary land is still sustainable, on the other hand it can provide legal certainty for investors and CLC, because rights are already made in the registration base map. Likewise if the above customary rights are burdened with rights as stipulated in State law (BAL and its organic rules).

\section{Conclusion and Recomendation}

\subsection{Conclusion}

Registration model for ulayat land in Pakraman Village in Bali after the issuance of Minister of Agrarian and Spatial Planning/The Head of National Land Agency Decree No. 276/2017 follows the pattern of registration stipulated in Minister of Agrarian and Spatial Planning/The Head of National Land Agency Regulation No. 10/2016, which equates communal land to communal land, or converts customary communal land with dimensions public as well as private become communal land which is only private dimension. With the PTSL program, customary land which has been controlled for generations individually has been issued a Certificate of Ownership in the name of Pakraman Village as was done in Tabanan, Badung, and Bangli.

\subsection{Recommendation}

In order to avoid extinction of the ulayat lands of Pakraman Village in Bali, the registration model can be followed by the guidelines stated in Minister of Agrarian and Spatial Planning /The Head of National Land Agency Regulation No. 5/1999 in conjunction with the Draft Law on Customary Community Rights for Initiative Law of the Republic of Indonesia 
DPD 2018, namely through registration in the form of a Basic Map of Land Registration by affixing a cartographic sign. Conceptually it is also intended to provide assurance and legal protection when communal land is cooperated with outside parties as capital assets or will be burdened with other rights known in the state law, so as to be able to provide benefits for the welfare of indigenous peoples.

\section{References}

[1] Regional Regulation of Bali Province No. 3 of 2001 jo No. 3 of 2003 concerning Pakraman Village

[2] Suwitra, I. M..: The Existence of Mastery and Ownership of Traditional Land in Bali in the National Agrarian Law Perspective. Doctoral dissertation. Universitas Brawijaya. (2009)

[3] concerning the Appointment of Pakraman Village in Bali Province as the Subject of Communal Property Rights on. Decree of the Minister of Agrarian and Spatial Planning/Head of the National Land Agency Number 276 / KEP-19.2 / X / 2017 dated October 23 (2017)

[4] Suwitra, I. M.: Conversion Impact in the BAL on Indigenous Land Status in Bali. Legal Journal IUS QUIA IUSTUM, vol. 17, no. 1, pp. 103-118 (2010)

[5] I. K. W. Puspadewi, A. Utama, I Made Arya.: Penunjukan Desa Pakraman Sebagai Subyek Hak Pemilikan Bersama (Komunal) Atas Tanah Berdasarkan keputusan Menteri Agraria dan Tata Ruang/Kepala Badan Pertanahan nasional Nomor 276/KEP-19.2/X/2017,” J. Ilm. Prodi magister Kenotariatan, vol. 1, pp. 215-232 (2018)

[6] Sudantra, I Ketut.: Certifying Indigenous Land in Bali: Mediation Implications for the Appointment of Pakraman Village as Subject to Communal Rights to Land, Paper, presented at the National Indigenous Land Seminar, Customary Law and Indigenous Law Community Organizations in. (2018)

[7] I. N. A. P. Suwitra, I Made.: Legal Certainty Perspective on Ulayat Land Ownership in Bali. Advances in Social Science, Education and Humanities Research (ASSEHR), vol. 282, pp. 97-100 (2018)

[8] Act No 5 year 1960 concerning Basic Agrarian Principles, LN 1960/104, TLN NO. 2043.

[9] Suwitra, I Made.: Registration of Right to Customary Land in Bali in the National Agrarian Law Perspective. Paper, was delivered at the Public Hearings Meeting in the context of Drafting the Draft Bill on Customary Land Rights in PPUU Meeting Room Lt.3 Gd. B DPD RI Jl. Gen (2018)

[10] Government Regulation No 24 Year 1997 tentangon Land Registration.

[11] Harsono, B.: Indonesian Agrarian Law History of Establishment of BAL Content and Implementation. Volume I of the National Land Law. Ninth print. Djambat. Jakarta (2003)

[12] Minister of Home Affairs Decree No. SK 556 / DJA / 1986 concerning Appointment of Pura as a Religious Legal Entity that can have ownership rights over land.

[13] Regulation of the Minister of Agrarian Affairs / Head of the National Land Agency No.5 / 1999 concerning Guidelines for Resolving the Rights of Ulayat Rights of Customary Law Communities.

[14] Minister of Agrarian Regulation No. 10 of 2016 concerning Procedures for Determining Communal Rights on Land of Customary Law Communities and Communities in Certain Areas.

[15] Sumardjono, M. S.: Kebijakan Pertanahan Antara Regulasi dan Implementasi. Jakarta: Kompas (2005)

[16] Yostina, M.: Communal rights to the land of indigenous and tribal peoples in Indonesia: Analysis of Minister of Agrarian and Spatial Planning Regulation Number 9 of 2015 concerning Procedures for Determining Communal Rights to Land in Customary Law Communities and Com.

[17] Suwitra, I. Made.: The Model of Registering the Right to Potato Land as a Giving of the King for the Preservation of Cultural Value Heritage in Karangasem Regency, pp. 399-418 (2018)

[18] concerning Second Amendment to Determination of Location of Acceleration of Implementation of Complete Systematic Land Registration. Decree of Head of Tabanan Regency Land Office Number: 69 / KEP.51.02,000 / V / 2018.

[19] Utrecht, E.: Introduction to Indonesian Law (6th Ed.). Jakarta: PT. Penerbitan dan Balai Buku Ichtia (1959) 